\title{
A theological assessment of clergy leadership capabilities in the Ethiopian Episcopal Church in South Africa
}

\author{
Dr. Zandisile M. Dweba - PhD Candidate \\ CEO and Lead Consultant Spontaneous Management Consulting, P. O. Box 3026, \\ Cambridge Southernwood, 5201, East London, South Africa \\ E-mail:zandidweba@telkomsa.net \\ Prof. Reuben Z. Rashe \\ Centre for Theology and Religion \\ University of Fort Hare, Alice, South Africa
}

Doi: https://doi.org/10.46222/pharosjot.102.028

\begin{abstract}
That theological training, only, may not be in itself adequate to prepare priests for their leadership roles, is a subject which many in the church circles, prefer to avoid. Using Mumford's Leadership Capabilities and Osmer's Practical Theology theories, this study sought to assess the clergy's leadership capabilities in the Ethiopian Episcopal Church in South Africa, and to suggest solutions that could be implemented to mitigate the leadership competency gaps, should such be identified. The authors opted for a mixed-methods approach to the study, intending to first expose the respondents to information about what capabilities leaders needed to possess, to be effective. Following self-assessment, they were requested to suggest what might be done to improve their leadership capabilities and their capacity to lead the church. The most compelling findings were that the clergy largely confirmed the inadequacy of clerical training as well as their incapacity and supported the idea of additional capacitation to augment their theological training. This includes a crossdisciplinary approach to clergy development, interdenominational collaboration, formalisation of clergy development programmes and open discussions on the church's doctrine, vision and values. The study also found sizeable support for the regulation of admission to the priesthood and the setting of minimum entry qualifications for such admission to be effected.
\end{abstract}

Keywords: Assessment, leadership, capabilities, foundationalism, post-foundationalism

\section{Introduction and background}

Whilst the current study was undertaken within the specific context of the Ethiopian Episcopal Church in South Africa (EECSA), the researchers considered it imperative that the broader social, ecclesiastical, political, economic and cultural contexts, against which the African Indigenous Churches and the EECSA, in particular, be understood. The EECSA, which provides the immediate setting of this study, is an African Indigenous Church, geographically distributed into five dioceses and 73 mission districts, throughout the Republic of South Africa. It has 123 clerics in its service, five of whom are bishops, 64 ordained priests-in-charge of mission districts and 54 deacons. Each of the five dioceses - James Mata Dwane (JMD), Ummandla weThemba, Ntaba ZoKhahlamba, Inqweba and Maropeng, is headed by a bishop, with the James Mata Dwane diocese, designated as the archdiocese. The bishop of the James Mata Dwane diocese assumes the role of the archbishop of the EECSA.

The study was inspired by the mounting pressure on the Christian churches globally, and within the EECSA, to embrace modern management and leadership approaches and techniques. There are even accusations that, in the absence of deliberate planning and 
measurement of the work of congregations, churches have become socially ineffective due to their lack of scientific management and sound leadership knowledge. It became apparent from the Ethiopian Episcopal Church in South Africa clergy's struggle with the implementation of the church's strategies of 2016 and 2022, that the Ethiopian Episcopal Church in South Africa is no exception to this censure. This study, which assessed the clergy's capabilities, using Mumford's Leadership Capabilities Model, is a response to the clergy's leadership capabilities challenge and was intended not only to identify capability gaps but to also propose solutions on how the church could best address the identified leadership capability gaps. In the study, existing knowledge and theories were borrowed and conceptual frameworks that systematically and fittingly assisted in identifying and addressing the contemporary leadership capabilities gaps in the Ethiopian Episcopal Church in South Africa utilised. This, the authors did, in an integrated and holistic approach, digging deeper and beyond just theorising about ideas, praxis and contexts (Moore, 1998; Roux, 2005).

Whilst it was not the intention of the authors to proclaim the study as a model interdisciplinary study, they did acknowledge the different theological, social and ecclesial contexts, proposed in Osmer's (2008) Practical Theology Model, which provides the backdrop against which this study is undertaken. The study adopted a post-foundational approach, which allowed for an interdisciplinary conversation, acknowledged contextuality and rationality in doing theology (Park, 2010). Kessler and Kretzschmar (2015) support this view when they assert that, for any Christian leadership study to do justice to the leadership phenomenon, it must be understood that, it is insufficient to confine itself within the discipline of Theology, as such other social science disciplines as Psychology, Sociology and Management Science, have a load of contribution to make. Against this understanding, the authors agree with Kessler and Kretzschmar (2015), that, the study of Christian leadership cannot be pursued in isolation. This view is backed up by Müller's (2017) assertion about the vulnerable location of Practical Theology, between the disciplines of Theology, humanities and social sciences that defies the nature of science, which is characterised by the exclusivity of disciplines.

\section{Problem statement}

The growth of the Christian church in Africa, has, over the years, baffled church administrators, theologians and missiologists. Whilst the growth of the Christian church in Africa is something to rejoice in, there is also cause for deep concern, as the more the church grows, so is the need for capable leaders. When the congregations become too large for a priest to oversee, it endangers the very congregants, whilst burning out the overstretched priest/s. The congregants must be nourished spiritually, directed and led by priests and church hierarchies. The African church needs its African Christian theology, taught by its theologians, within the church itself. While the demand for appropriately qualified clergy is increasing, more and more graduates seem to be reluctant to join the ministry. Because of this indifference, many churches have opted to ordain the willing, who may not necessarily have the requisite aptitude, qualifications or even personalities to serve as required. This, Douglas (2014) observes, has led to many African churches establishing informal, unconventional and non-accredited clergy development programmes, with no clear pattern or clearly defined outcomes.

The problem which triggered this research, was the observed inability of the clergy to lead their congregations effectively, presenting the Ethiopian Episcopal Church in South Africa with a challenge of not being able to achieve its strategic goals. As the situation stood, the church had neither the knowledge of what leadership capabilities the clergy needed to possess nor comprehension of the gravity of the resultant leadership capabilities gaps. There were also no mechanisms in place, to impart the requisite leadership capabilities. This prompted the need to assess the current state of leadership capabilities among the clergy in the Ethiopian Episcopal Church in South Africa; the extent to which the clergy possessed leadership capabilities in the Ethiopian Episcopal Church in South Africa; and to propose practical 
solutions which could be utilised to address the capability gaps of the clergy in the Ethiopian Episcopal Church in South Africa. Whilst the problem was investigated within the Ethiopian Episcopal Church, other black denominations are not immune to this linear competence of the clergy.

\section{Literature review and theory discussion}

Leadership development is of paramount importance for organisations with a strategic vision, whether these are government, private or faith-based organisations. Leadership success rests on the foundation of existing development practices and is anchored on three pillars, namely, institutional training and education interventions, competency-based assignments and personal initiatives. Any attempt to study leadership for churches, whether it is about leadership styles, leadership development or competencies, must, therefore, be treated as a special case of theory and practice, that, whilst differing fundamentally from what the disciplines of behavioural and social sciences have contributed, the study of the phenomenon, in the church, presents a challenging "divine heart-shaping" dimension (McNeal 2000:31), that may, at times, elude rigorous empirical scrutiny. Leadership in the church environment, cannot be explored without due cognisance of the role of unctioning or anointment - the special calling, preparation and God's gifting, of a leader, which may not necessarily feature in the research work of social and behavioural sciences (McNeal, 2000; Roux, 2005).

Against this backdrop, church leadership must embrace a new way of doing their missional work, that takes the community on board when conducting congregational ministry, which, whilst appreciating the missional calling of the church, consciously involves the church and its leadership within the society and how things are done beyond the disciplinary confines of Theology. There is an urgent call for church leaders to understand their role and the capabilities they need to possess to fulfil that role. They must recognise their congregations as contextual realities that should not elude their mission call and the interaction with their contexts. It is essential, against this backdrop, to understand the contextual nature of Theology, whilst simultaneously appreciating that, from a practical theological perspective, Theology cannot simply be downloaded onto a local situation. It must take the church's contextual realities into account (Hendriks, 2006; Niemandt, 2013; Nel \& Schoeman, 2015).

The foregoing is supported in Macallan and Hendriks' (2012), that, Practical Theology has transcended the foundationalist premise, of merely accepting that, not all our beliefs, are on the same level, but some beliefs do anchor others. Grenz and Franke (2001), clarify in their statement that, some of our assertions receive their support from other beliefs, that are more foundational. Foundationalists, in their assumptions, hope to anchor all knowledge, on guaranteed certainty and the elimination of error. Post-foundationalists refute this view, as argued in Van Huyssteen's (1997:13) assertion, that, “In theological reflection then, a postmodern critique of foundationalist assumptions will therefore be an inextricable part of a post-foundationalist model of rationality, and will shape how theology is located within the context of cross-disciplinary reflection". In an attempt to take a contextual view of both the study of church leadership and Practical Theology, a post-foundationalist approach must be adopted in this study.

Park (2011) supports this view when he writes that, Practical Theology recognises the context, interprets existing knowledge and incorporates Christian models and norms of Christian practice. He argues that this process builds into it, hermeneutics and epistemology. For it to be transformative, it must be couched within a post foundational theological framework, that enables cross-disciplinary engagement and contextual interpretation. Whilst this study is not arguing for postfoundationalism in all situations, it does subscribe to transversal reasoning, interdisciplinarity and interpreted experience to give effect to the subject matter of the study. This is contrary to foundationalism, which is premised on inflexible holding onto a position, 
regardless of the context, and invokes absolute foundations that lead to the building of an evidential support system for convictional beliefs and assertions (Van Huyssteen, 1997).

Having explored the benefit of adopting a post foundational approach in this study, the way was paved for the two proposed theories which the authors proposed, to guide this study; Osmer's Practical Theology Model and Mumford's Leadership Capabilities Model. The Theological reflection offered in post-foundationalism, as will be evident, guides the discourse beyond the disciplinary confines of Theology, and towards a plausible form of a crosscontextual conversation.

\section{Osmer's Practical Theology Model}

The relevance and applicability of Osmer's model in this study were on how it asserted that practical theology is about listening to the varying and at times disagreeing voices from both the context and text. Whilst listening can, sometimes, be unstructured and informal, it is recognised as a proper process for empirical research (Osmer, 2008:37). As a crucial and integral element of practical theology, therefore it must provide for a reliable methodology. Input from the context about church life, he argues, must provide a backdrop against which conclusions can be drawn and generalisation avoided. This is the essence of the current study, whose thrust, was to explore the study topic, describe the situation and events and explain, where need be, whether or not, there was a causal relationship between the variables and the events (Babbie \& Mouton, 2001; Fouchè \& De Vos, 2011).

Osmer (2008) asserts that, answering the questions of what, why, how and what ought to, is at the core and is central to the praxis and interpretation in practical theology. Osmer's contention supports the objectives of the current study, which sought to respond to these four questions as they related to the leadership capabilities of the Ethiopian Episcopal Church in South Africa clergy. The mixed-methods approach adopted in this study sought to elicit both the descriptive information from the respondents as well as their reasons or explanation for the descriptive information provided. The intention was, as Osmer suggests, to allow for the respondents to exercise judgement, thoughtfulness and a reasoned theoretical interpretation. Osmer refers to the Normative Task, as seeking to discern God's will for the present reality (Smith, 2010:107). He argues that this prophetic discernment is intended to articulate the interchange between the human shaping of God's word and the divine disclosure. In it, three methods are proposed; ethical reflection, good practice and theological interpretation (Osmer, 2008:134-135).

\section{Mumford's Leadership Capabilities Model}

Mumford's Leadership Capabilities Model, which, in collaboration with Osmer's Practical Theology Model, underpin the nature of the capabilities in this study, propose that leadership cannot be limited to people with so-called 'born with leadership traits'. It implies that there are many people within an organisation or a congregation, that may possess leadership potential, provided they are ready to be capacitated for the task. Mumford's view is that leaders must not only be task-matured or understand the organisational context but essentially, need to master the social context within which their organisation operates. This is consistent with the post foundational approach to practical theology, recommended in this study. Schwartz (2017), Barna (1997), Welch (2005) and Stewart (2008) hold that the diminishing effectiveness of church leaders, can partly be blamed on the linear nature of the clergy's theological training, which they contend, is neither adequate nor does it sufficiently prepare them to deal with most eventualities of leading congregations. The authors attempt to unpack this model and argue its value-add in a church context (Mumford et al., 2000; Mumford et al., 2007)

The church must balance its view of leadership, to allow the clergy to draw benefits from both the biblical as well as managerial competency pools. This is, especially significant, if the 
church, must be accepted as the society's conscience, on moral, political and socio-economic matters (Hellriegel et al., 1992). Whilst the foregoing may be understood to suggest that, for the effectiveness of the organised church, ministers must be competent on both the biblical and secular models of leadership, the authors must caution that, some of these modern management and leadership (secular) approaches, may not be readily received by some church leaders.

Mumford's Leadership Capabilities Model follows the leadership skills approach and adopts a leader-centred viewpoint that incorporates acquired capabilities, complemented by the leader's innate traits, experiences and context. It emphasises the capabilities that can be acquired and improved. The foregoing does, in no way, suggest underplaying the importance of leader personality, as the personality of the leader contributes immensely to leader competence (Bass, 1990; Northouse, 2015). The key insights offered by Mumford's Leadership Capabilities Model, are that the leader must solve indeterminate, unclear and illdefined problems. To resolve these complex problems, leaders must possess the requisite personal competencies. In the Christian context, leaders need to espouse Christian ethics which applies to the Christian faith and positive servant leadership motivations based on deep spirituality. This is needed to link in a manner that allows for the desired principles, standards, and procedures for actions and a set of divinely inspired virtues to be in place with relevance to all clerical activity (Nicolaides, 2020).

Finally, the effectiveness of leaders does not always lead to organisational effectiveness, unless the requisite capabilities are also developed and demonstrated among the followers (Mumford \& Connelly, 1991; Mumford et al., 2000; Stewart, 2008).

\section{Research design and methodology}

The study is both exploratory as well as descriptive, in that, the authors sought to explore the prevalence of leadership capabilities and describe the perceived demonstration of these capabilities among the clergy in the Ethiopian Episcopal Church in South Africa. Whilst the authors opted for a mixed-methods approach to this study, the study was also synthetic, in that, the appropriate and relevant work of various scholars and practitioners was ascertained, assembled and analysed to shed insight and arrive at informed conclusions. The mixedmethods approach in this study offered a unifying framework that incorporated spaciality.

The Likert scale which the authors used was a structured technique, which indicated the respondents' level of agreement or disagreement with a given statement, concerning the phenomenon being studied. Once an agreement or disagreement had been expressed through the selected preference in a unipolar semantic scale, which measured a leadership capability's direction and intensity, simultaneously, using a progression arrangement from 'very true' to 'not true', the respondents had to explain qualitatively, what they thought might be done to improve the status quo (Carifio \& Perla, 2007; Lantz, 2013). As it became inevitable that, with the advent of the Covid-19 pandemic, travel restrictions and the compulsory maintaining of social distance, following the paper-based data collection approach, would not be possible, the authors, digitised the questionnaire and distributing it by internet (Denscombe, 2006).

Quantitative data were captured and analysed using the Statistical Package for Social Sciences (SPSS) while the qualitative data was thematically analysed, aggregated and conclusions are drawn. As part of the mixed-methods approach, data were tested for congruence with the research theories, the research objectives and the research questions. Demographic data collected, were analysed using descriptive statistics to help understand each variable. Each variable of the data was described in terms of frequencies, percentages, means, modes, averages and standard deviation, to know the sample distribution and 
summarise the characteristics of large sets of data. Following the presentation of findings and drawing of conclusions, the report was presented for assessment.

Whilst the authors followed a purposive sampling approach, they continued canvassing until each diocese and clergy category was adequately represented in the final sample (Saunders et.al., 2012). Saunders et al. (2012) and Bless et al., (2013), agree that a 95\% confidence level is adequate for both Theology and Social Sciences in general. From a population of 123 ordained priests, an estimated sample of 94 respondents was drawn, ensuring that all the dioceses were adequately represented. The questionnaire was thus, distributed to all 94 potential respondents.

The authors presented, analysed, interpreted the collected raw data, drew conclusions and reported the findings of the empirical study. This exercise was intended to organise and present the data in a meaningful way, to enhance and reveal its fundamental characteristics. Once the data had been collected, it was captured and analysed quantitatively using the Statistical Package for Social Sciences (SPSS) and the qualitative data were thematically analysed, aggregated and conclusions drawn. Demographic data were analysed using descriptive statistics to give character to the inferential statistics. As part of the quantitative statistics, the authors undertook a correlation exercise using Spearman's rho correlation test. Data symmetry and peakedness were measured using the Skewness and Kurtosis tests. The Kaiser-Meyer-Olkin (KMO) and Bartlett's test was undertaken to determine sample adequacy. The Chi-squared test was undertaken to determine whether observed sample frequencies differed significantly from expected frequencies as could have been specified in the null hypothesis. The findings were consolidated, conclusions drawn and recommendations made.

\section{Ethical considerations}

As scientific research is founded on the belief that research outcomes are valid and reflect a sincere effort by the researcher to portray an accurate account of the world without bias, the authors did not only commit but set an example by complying with the set research ethical standards. They maintained the absolute anonymity of the respondents. Whilst written permission was obtained to undertake the study, the respondents' informed consent was sought and the respondents had the right to withdraw their participation at any point if they felt uncomfortable with the study. The required Ethical clearance was applied for and obtained from the University of Fort Hare's Research Ethics Committee (UREC) before the commencement of the study. All the sources cited in the study, are appropriately referenced to acknowledge the contribution made by the authors.

\section{Major Findings}

The major study findings in this article are organised based on the findings from the literature reviewed and the findings from the empirical study.

\section{Findings from the literature reviewed}

While organised religion remains a potent social institution, the literature reviewed in this study, exposed signs that the traditional approach to church leadership, whether this is in congregational or faith-based settings, remains vulnerable. The inadequacy of clergy training, which the priests cited as being among the reasons why they experience difficulties in performing their leadership roles, can no longer be disregarded. Unless solutions are sought and found, not only within, but also beyond the disciplinary confines of Theology, there does not seem to be any solution in sight. Scholars argued in the literature, that, church leaders must embrace a new way of doing their missional work, that takes the community on board when doing the congregational ministry, which, whilst appreciating the missional calling of the 
church, consciously involves the church and its leadership within the society, for them to appreciate how things are done beyond the disciplinary confines of Theology.

The inadequacy of clergy leadership training and capacity is not only confirmed but its possible causes are proposed and solutions, some from beyond the theology disciplinary boundaries, advanced. Among the glaring clergy leadership behavioural manifestations, literature exposed, are over-functioning church leaders, who try to do and decide everything, resulting in the stifling of church processes; non-functioning clergy, who do not lead, but watch as the church falters; leaders with inadequate training, which renders them incapable of performing optimally; inappropriately trained leaders, who lack doctrine-specific training, for the churches they lead; over-extended leaders, who monopolise all the pastoral and sacramental functions, seeking to uphold the artificially high western standards of ministry, whilst denying the priesthood of believers; and, springboard leaders, who use the church leadership training programmes and facilities, as springboards to secure better-rewarding positions elsewhere.

A further flaw, the reviewed literature revealed, is the oversimplistic view of leadership by the clergy, as almost a unidimensional character trait, that can easily be developed through spiritual discipline and devotion, alone. This was seen, by many scholars, as inadequate for the holistic leadership of a congregation. As a result of this linear approach to leadership, such contingency factors, as follower dimensions, process skills, behavioural skills, group dynamics, organisational culture and many other contextual variables which influence the social interaction processes of leadership, are not sufficiently taken into account. The consideration of these factors, unfortunately, did not appear to be evident in the way the Ethiopian Episcopal Church in South Africa clergy leads.

That the acquisition of leadership capabilities was not prioritised, could equally be attributed to the erroneous underplaying of the importance of leadership development for the clergy. The leadership programmes, that do not only focus on the biblical view of leadership but also the modern management and leadership views, currently offered by various denominations globally, were seen as evidence of the growing interdependence between the disciplines of Theology and social sciences. The harmonious interplay between Mumford's Leadership Capabilities Theory (a social science theory) and Osmer's Practical Theology Theory in this study, it can be safely concluded, is evidence of a successful and mutually beneficial collaboration between Theology, social sciences and humanities, to derive solutions for church leadership. While it was Mumford's Leadership Capabilities Theory that helped outline the leadership capabilities that the clergy needed, it was only in collaboration with Osmer's Theory of Practical Theology that the path was drawn, to the resolution of the problem statement.

Finally, the pragmatic element of Osmer's Model brought about the operationalisation of an appropriate response to the study's problem statement. The response to the question of, How might we respond? was informed by the quality of leaders and what leadership capabilities they demonstrated, the situation and the resources at their disposal. It had to bring about improvement to the status quo.

\section{Findings from the empirical study}

The statistics in both the descriptive and inferential statistics responded to the research questions of what the current state of leadership capabilities among the clergy in the Ethiopian Episcopal Church in South Africa was, and to what extent the clergy possessed the requisite leadership capabilities for the Ethiopian Episcopal Church in South Africa? 


\section{a) Demography}

The responses that were received from the dioceses were distributed in the same manner that the clergy population is, among the dioceses. This distribution reassured the authors that, all the five dioceses were proportionately represented. That more priests had more than 10 years' service and much fewer priests who had less than one year, confirmed the current situation within the Ethiopian Episcopal Church in South Africa.

Whilst $31 \%$ of the priests claimed to possess post-graduate qualifications, some of these, it was discovered, were non-theological qualifications. The clergy numbers are, in reality, dominated by priests in the lower echelons of the academic hierarchy, with either a diploma, certificate or other qualification, that may be lower than a certificate. This distribution revealed that the clergy population in the Ethiopian Episcopal Church in South Africa was dominated, at $92 \%$, by clergy older than 40 years. The recent stream of retirements and the recalling of retired priests is a sign of an ageing clergy population. The $77 \%$ male domination, is the aftermath of the delayed admission of women into the priesthood, as it was only in 1997, that the first woman was ordained as a priest.

\section{b) Response analysis}

The respondents refuted the statement that their training could be adequate. This view was further strengthened by the respondents' overwhelming $(68,8 \%)$ rebuttal of the statement that they did not need additional training. The rejection of the statement that clergy training covered all aspects of their role, by $77,1 \%$, was a further confirmation that, indeed, their training was not adequate and the admission, by $64,4 \%$, that the church's clergy, did not possess all the necessary skills for them to be effective, was a further confirmation that the clergy's training was far from adequate.

More than $66 \%$ of the respondents confirmed that they enjoyed and were fascinated by getting into the details of how things were done in their roles - with over $91 \%$ of them, even bragging that they possessed the skill of 'making things happen'. Interpersonal capabilities. While acknowledging that they may not possess the requisite interpersonal capabilities, the respondents seemed to understand the importance of possessing these capabilities in their roles. They also acknowledged the importance of knowing how people were organised in the church and how congregant structures needed to work together, in the best interest of all. The respondents confirmed that they were always concerned about how their decisions affected the congregants. Understanding the importance of these capabilities was one thing, but whether or not these were demonstrated, is a matter which the church may need to follow up on.

Whilst the respondents seemed somewhat divided on whether or not they enjoyed working and discussing intangible ideas and things, and seeing the big picture, the endorsement of the statement, "I would enjoy working out strategies for my church's growth", by $71 \%$, does show the keenness of the clergy, to be involved with complex strategic issues of the church. This was also supported by their $68,7 \%$ expression of their desire to, "Participate in the creation of the church's vision and mission statement is satisfying to me", and their fascination with the idea of, "....understanding the church's doctrine, values and philosophy".

Whilst there was not a clear tilt on all the statements in the problem-solving dimension, there was an evident inclination towards enjoying taking control of complex problems, foreseeing problems before they occur, questioning problem assumptions, gathering important and relevant information to help solve problems and using strategic tools, learnt from their clergy training. That the clergy indicated by a marginal majority that, they were "...fascinated by the 
complex doctrinal, leadership and strategic problems of my church", was a good indication, as this is a leadership capability they need to guide congregants.

Finally, the majority of the respondents confirmed that they possessed the administration and governance capabilities, whilst admitting to knowing all administrative procedures that are there to know in the church. Only $37,0 \%$ admitted to understanding the church's governance structures and how they operated. Very few respondents admitted to possessing adequate financial skills $(25,0 \%)$. Less than half $(45,8 \%)$ admitted that their mission districts had clear plans, which were aligned with the church's overall strategy. Diocesan and mission district plans must flow from this church-wide strategy. Any misalignment has the potential for the activities of the lower structures, not to contribute to the broader church vision. For more than $50 \%$ of the respondents to concede that their plans might not be aligned with the main vision of the church, though, is a situation which the church cannot allow to continue.

\section{Findings from the inferential statistics}

\section{a) Correlation Analysis}

The Spearman's rank correlation undertaken, revealed strong to very strong correlations, ranging from .60 to $>.80$, which were significant at either 0.01 level (2-tailed) ${ }^{* *}$ or at 0.05 level (2-tailed) *. What this statistical significance meant for the study, is that the correlations between these variables are caused by something other than chance. This also meant that there must be an underlying explanation of why the items are correlated; that, based on the sample information, conclusions can be drawn about the population correlation coefficient. While several incidents of negative correlation were evident, they were all weak and statistically insignificant, meaning that, the correlations may be by mere chance.

\section{b) The Kaiser-Meyer-Olkin (KMO) test results}

The $0.655 \mathrm{KMO}$ measure of sample adequacy confirmed that the sample used in the study was adequate, indicating adequate inter-correlations between the indicators and the suitability of the factor analysis. This was important because its presence meant that there were no interrelationships among the items.

\section{c) Tests of Significance - Chi-Square (x2)}

The various Chi-squared cross-tabulations that were done, revealed that:

- Whether or not priests in different dioceses found their training as adequate, this was found to be insignificant, suggesting that the priests' location did not affect how they perceived their training adequacy;

- Whether the priests were male or female, were fascinated by the technical aspects of their role, was found to be insignificant, suggesting that, this had no impact on this aspect of their role;

- Priests' qualifications were found to be significant $(X 2(2)>=21.866, p=0 . .148)$, and that, priests who possessed higher qualifications, were found to be more able to solve complex problems. This meant that the priests' qualifications influenced their ability to deal with complex problems;

- While there was no significant association between the priests' length of tenure with whether or not they possessed administrative skills, $(X 2(1)=16.762, p>.159)$, clergy who had a longer tenure as priests, had better administration skills; and 
- No association was found between the location of a priest in a particular diocese and their possession of administration skills $(X 2(2)>=13.371, p=0.645)$.

\section{Findings from the qualitative analysis}

These findings were drawn from the respondents' input, in response to, particularly, the third research question of what practical solutions could be utilised to address the leadership capability gaps identified among the clergy in the Ethiopian Episcopal Church in South Africa. The respondents gave input to the specific questions posed in each of the six dimensions in the questionnaire, as to what they thought could be done to improve the adequacy of their training, their technical capabilities, interpersonal, conceptual, problem-solving capabilities, administration and governance capabilities of the clergy. The respondents were of the view that the clergy should be provided with training in the form of internal programmes or workshops/conferences/seminars, facilitated by external experts. They suggested that admission to priesthood be regulated, to include the use of assessment tools, prescription of minimum entry qualifications and the implementation of accredited training programmes. They also suggested the strengthening of the church's current training institutions like the Sigqibo Dwane Continuing School of Theological Education and/or the establishment of new ones. The respondents made two strong suggestions regarding technical capabilities, that, a formal mentoring programme be developed, qualified mentors identified from within and beyond the Ethiopian Episcopal Church in South Africa, and implemented for deacons and/or trainee priests. They recommended that church rituals be standardised to prevent regionalisation and inconsistent practices.

The respondents recommended that the church develops and implements mechanisms to improve the dissemination of knowledge and general information; and to introduce selection instruments, to help with the selection and placement of the clergy. They further suggested that the church opens up a dialogue about the church's doctrine, vision and values, for the knowledge about these phenomena to filter down to the lowest levels of the congregation. They were of the view that, the church's doctrine, vision and values, must be included in all levels and agendas of teaching, included as an explanatory section in the church's prayer book and printed on posters which must be visibly displayed in all church buildings. Concerning problem-solving, the respondents suggested that the church utilises capable and professionally qualified congregants who might be better qualified to help deal with certain types of problems; and to encourage its clergy to set up mission district structures with professional capacity. This, it was added, would ease their workload, while providing mechanisms for the escalation of problems where decisions must be taken at the highest levels. The respondents suggested that, over and above the standardisation of the church's operating procedures, it must utilise uniform templates, across all the dioceses for capturing information and reporting, this, they asserted, would facilitate consolidation at the higher levels. The need for the provision of feedback to submitted reports, with suggestions for improvement, would go a long way towards the resolution of the church's administrative problems. The church must encourage its senior leaders, including the bishops, at various levels of the church hierarchy, to pay regular visits to mission districts, boost the morale of the congregants and provide guidance to priests, especially in remote locations.

\section{Recommendations and conclusions}

Examining church leadership, using leadership theories and models from beyond the boundaries of Theology, it can be safely concluded, has added the much-needed insight and perspective in enriching clergy leadership development in the Ethiopian Episcopal Church in South Africa. Drawing from the rich social sciences leadership research reserves, has particularly, illuminated this study and laid the foundation for the implementation of the recommended interventions. Following this study, the possibility of integrating leadership 
development as part of the broader clergy training has the potential to lead to the development of a broad-based training approach for the current and future leaders of the Ethiopian Episcopal Church in South Africa. The Ethiopian Episcopal Church in South Africa's clergy's understanding of the complex societal environment, within which they minister, will be better understood and documented. The leadership capability gaps were identified and the proposed solutions implemented, for the first time to mitigate the leadership capabilities gaps in the Ethiopian Episcopal Church in South Africa. The findings could, especially concerning the orientation of freshly qualified priests, be extended to contexts, beyond the Ethiopian Episcopal Church in South Africa.

\section{References}

Babbie, E. \& Mouton, J. (2001). The Practice of Social Research: South African Edition, Oxford University Press Southern Africa, Cape Town.

Babbie, E. \& Mouton, J. (2005). The Practice of Social Research, Oxford University Press, Oxford.

Barna, G. (1997). Leaders on Leadership: Wisdom, Advice and Encouragement on the Art of Leading God's People: The Leading Egde Series, Regal Books. Ventura, CA.

Bass, B. M. (1990). Bass \& Stogdill's Handbook of Leadership: Theory, Research, and Managerial Application (3rd ed.), Free Press, New York.

Bless, C., Higson-Smith, C. \& Sithole, S. L. (2013). Fundamentals of Social Research Methods: An African Perspective (5th ed.), Juta, Cape Town.

Carifio, J. \& Perla, R. J. (2007). Ten Common Misunderstandings, Misconceptions, Persistent Myths and Urban Legends about Likert Scales and Lickert Response Formats and their Antidotes, Journal of Social Sciences, 3, 106-116.

Denscombe, M. (2006). Web-Based Questionnaires and the Mode Effect: An Evaluation Based on Completion Rates and Data Contents of Near-Identical Questionnaires Delivered in Different Modes, Social Science Computer Review, 24 (2), 246-254.

Douglas, S. M. (2014). Developing Leaders for Pastoral Ministry, The Journal of Applied Christian Leadership, 8 (2), 84-90.

Fouchè, C. \& De Vos, A. (2011). "Formal Formulations". In A. De Vos, H, Strydom, C B Fouchè \& C S L Delport (eds), Research at grassroots for the social and human service professions, pp. 89-100, Van Schaik Publishers, Pretoria.

Grenz, S. J. \& Franke, J. R. (2001). Beyond Foundationalism: Shaping Theology in a Postmodern Context. Westminster, Louisville.

Hellriegel, D., Slocum, J. W. \& Woodman, W. W. (1992). Organizational Behaviour, St. Paul, Wets Pub Co.

Hendricks, O. M. (2006). The Politics of Jesus: Rediscovering the True Revolutionary Nature of Jesus Teachings and How They Have Been Corrupted, Three Leaves Press, New York, NY.

Kessler, V. \& Kretzschmar, L. (2015). Christian Leadership as a Trans-disciplinary Field of Study, Verbum et Ecclesia, 36(1). pages.http://dx.doi.org/10.4102/ve.v36i1.1334.

Lantz, B. (2013). Equidistance of Lickert-type Scales and Validation of Inferential Methods Using Experiments and Simulations, Electronic Journal of Business Research Methods, 11 (1), 16-28. 
McNeal, R. (2000). A Work of Heart: Understanding How God Shapes Spiritual Leaders, Jossey-Bass Publishers, San Francisco.

Moore, M. (1998), Toward a Useful Consensus, IDS Bulletin, 29(2), 39-48.

Moore, M. E. (2003). Poverty and Violence: An Eschatological Vision, International Journal of Practical Theology, 7(1), 39-59.

Mumford, M. D. \& Connelly, M. S. (1991). Leaders as Creators: Leader Performance and Problem-solving in III-defined Domains, Leadership Quarterly, 2, 289-315.

Mumford, M. D., Hunter, S. T., Eubank, D., Bedell, K. E. \& Murphy, S. T. (2007). Developing Leaders for Creative Efforts: A Domain-based Approach to Leadership Development, Human Resource Management Review, 17, 402-417.

Mumford, M. D., Scott, G. M., Gaddis, B. \& Strange, J. M. (2002). Leading Creative People: Orchestrating Expertise and Relationships, The Leadership Quarterly, 13, 705-750.

Mumford, M. D., Watts, L. L. \& Partlow, P. J. (2015). Leader Cognition: Approaches and Findings, The Leadership Quarterly, 26, 301-306.

Mumford, M. D., Zaccaro, S. J., Harding, F. D., Jacobs, T. \& Fleishman, E. A. (2000). Leadership Skills for a Changing World: Solving Complex Problems, The Leadership Quarterly, 11 (1), 11-35.

Mumford, M. D., Zaccaro S. J., Harding, F. D., Fleishman, E. A. \& Reiter-Palmon, R. (1993). Cognitive and Temperament Predictors of Executive Ability: Principles for Developing Leadership Capacity, U.S. Army Research Institute for the Behavioral and Social Sciences, Alexandria: Virginia.

Mumford, T. V., Campion, M. A. \& Morgeson, F. P. (2007). The Leadership Skills Strataplex: Leadership Skills Requirements Across Organizational Levels, The Leadership Quarterly, 18, 154-166.

Müller, J. (1991). African Contextual Pastoral Theology, Scriptura, 39, 77-88.

Müller, J. C., (2005). A Postfoundationalist, HIV-positive Practical Theology, International Academy of Practical Theology, Brisbane, Australia.

Müller, J. C. (2017). African Postfoundational Practical Theology, Acta Theologica, 37 (1), 86-96.

Nel, P. C. \& Schoeman, W. J. (2015). Leadership in Rural Congregations and Communities: An Exploration in the North-Eastern Free State, Acta Theologica, 22, 153-170.

Nicolaides, A. (2020). Contemplating Christian ethics and spirituality for sound leadership in organisations, Pharos Journal of Theology, 101: a.37.

Niemandt, N. (2013). Nuwe Leiers vir Nuwe Werlikhede, CUM, Vereeniging.

Northouse, P. (2015). Trait Approach. In Leadership: Theory and Practice (7th Ed.), SAGE Publications, Thousand Oaks, CA.

Osmer, R. (2008). Practical Theology: An Introduction, Wm: B. Eerdmans Publishing Co, Grand Rapids.

Osmer, R. R. (2011). Practical Theology: A Current International Perspective, HTS Teologiese Studies/Theological Studies, 67(2), http://dx.doi.org/10.4102/hts.v67i2.1058.

Park, S. K. (2010). A Postfoundationalist Research Paradigm of Practical Theology, HTS Teologiese Studies/Theological Studies, 66(2). DOI:10.4102/hts.v66i2.849. 
Park, M. S. \& Smith, R. R. (2011). "Interview by Author" [Interview] (19 October 2011).

Roux, C. H. (2005). "The Contribution of Strategic Management and Organisational Development Theory, Models and Practice to the Effectiveness of Local Churches", Doctoral Thesis, University of Stellenbosch, Stellenbosch.

Saunders, M., Lewis, P. \& Thornhill, A. (2012). Research Methods for Business Students, Harlow, Pearson.

Schwartz, C. (2017). On Threefold Revelation of God, Journal of Applied Christian Leadership, 10(2), 16.

Smith, K. G. (2010). Review of Richard Osmer, Practical Theology: An Introduction, The Journal of the South African Theological Seminary, 10(1), 99-113.

Stewart, A. C. (2008). The Workplace of the Organised Church: Theories of Leadership and the Christian Leader, Culture and Religion, 9(3), 301-318.

Strydom, H. (2005). "Sampling and sampling methods", In de Vos, A. S., Strydom, H., Fouché, C. B. and Delport, C. S. L. (3rd ed.), Van Schaik Publishers, Pretoria.

Van Huyssteen, J. W. (1997). Essays in Postfoundational Theology, WmB. Eerdmans, Grand Rapids, MI.

Welch, R. W. (2005). Church Administration: Creating Efficiency for Effective Ministry, Broadman \& Holman Publishers, Nashville, TN. 